\title{
The State of ICT Integration in the Early Years in Ghana Schools
}

\author{
Joyce Nsiah Asante \\ University of Education, Winneba \\ Ghana
}

\begin{abstract}
This study investigated the status of ICT use in early childhood education in Ghana. It explored the availability of some technological resources in two hundred and fifty (250) schools from three regions in Ghana. It was also to understand the current state of technology integration in the early childhood classrooms. Each participant was conveniently selected from each school for the study. Participants responded to a Researcher made questionnaire which sought to find out the type (s) of technological resources available as well as teachers' background in ICT. Fifty (50) out of the (250) participants were selected purposively and interviewed. The study revealed that the integration of ICT in Ghana's early years' classrooms is not encouraging especially in the public schools. The computer was identified as the most used technological resource available in the various schools. Though the findings suggest the participants hold a positive perspective of the importance of ICT integration in the early years, $60 \%$ of participants teaching at the early years have no knowledge in ICT and $67 \%$ of them do not integrate it in their teaching. It is recommended that pre service teachers and teachers be purposively trained on the use and integration of ICT in teaching.
\end{abstract}

\section{Introduction}

In today's world, ICT is a ubiquitous component of our life. Most of the things we use incorporate ICT. The rapid development in Information Communication and Technology has made tremendous changes in the twenty-first century, as well as affected the demands of modern societies. Recognizing the impact of new technologies in our daily lives, today's educational institutions try to restructure their educational programs to incorporate technology and now Technology use plays a major role in education. Currently, ICT and "e-learning" have become important concepts in Primary, Senior High Secondary, and tertiary education in Ghana. Though Ghanaians are not highly developed in technology use as compared to the advanced countries, Ghana can be counted among the nations which see the integration of technology in education as very essential. In its tertiary education, students are being engaged in on-line learning [1], [2]. Learning platforms such as online educational videos, virtual classrooms, webcasting and an array of access to research, all compiled on the internet provides convenience for both students and lecturers and this, in its own way, has reinvented the way Ghanaians view education [3]. Many tertiary and second cycle schools employ the use of technological resources like projectors, internet, computers and microphones to enhance lesson delivery [4]. In addition, basic school students are assessed on ICT as a subject in their final exams.

However, the situation seems to be different at the lower level of education in Ghana especially at the early years. Early Years generally refers to children from birth to age eight, and the community of educators and various sites associated with the care and education of this age group. For the purposes of this paper, children's classrooms in the age range of 3 to 8 years are the focus group.

\section{Background}

ICT matters in early childhood education; this is because it already has an effect on the people and the environments that surround young children's learning and well-being [5]. This implies that from their earliest years, children should be finding out about and identifying the uses of technology in their everyday lives [6]. They should also be made to using computers and programmed toys to support their learning. Children need the opportunity to explore and play with computers as well as other forms of ICT, such as cassette recorders. This kind of play acts as the foundation for more structured use of applications later on. It means that ICT must be integrated across the curriculum.

ICT allows us as a people to get information, to communicate with each other, or to have an effect on the environment using electronic or digital equipment. ICT in early childhood education (ECE) could include different types of hardware and software [6]. It includes computers (including desktop, laptop, and handheld computers); digital video cameras and digital cameras; creativity and communication software 
and tools; the Internet; telephones, fax machines, mobile telephones, tape recorders; interactive stories, simulated environments, and computer games; programmable toys and "control" technologies; videoconferencing technologies and closed-circuit television; data projectors, electronic whiteboards, and more.

From the above, it is therefore to ensure that Ghanaian children have access to ICT which offers them opportunities to develop general skills and also extend their specific knowledge of that technology. Meanwhile observation made by the researcher in a number of schools around the country does not suggest much is being done. It is against this background that the researcher explored to find out how many of the named technological resources are available in most Ghanaian schools, whether teachers are able to integrate ICT at the lower level of education precisely the kindergarten through to primary 3.

\subsection{The debate - Current Trends of ICT in Early Childhood Education}

A look at researches [5], [8], [9], [10] in education over the years as well as several similar ICT frameworks [11]; [12] in other countries indicate the emphasis being made on ICT in the Early Years. It can be seen from literature that a number of the studies [13]; [5] express safety concerns with respect to integration of ICT in early childhood education and warn of several risks in this area. Some critics [14]; [15] contend that technology in schools wastes time, money, and childhood itself by speeding up the pace and cutting down on essential learning experiences. An argument opposing early introduction of ICT is that since children learn through their bodies, computers are not developmentally appropriate [16]. This is because as a screen-based medium, activities at the computer are not as effective as manipulative in developing understanding and skills in the early years [17]. [18] also in his Curriculum Corporation commissioned report cautions about introducing computer- based learning into Preschools and the first years of school. He instead recommends that the developmental needs of young learners (wholebody movement, sensory interaction, focus on language, development of personal agency and the importance of relationships) take precedence in structuring effective early learning programs.

In contrast to the above, current case studies and action research, such as the Children of the new millennium ICT research project, refute this view. It is widely accepted that appropriate use of ICT in settings, where there are skilled practitioners and quality ICT resources, has the potential to greatly enhance and support learning and development of young children [19]. For example,
[20] considered the appropriateness of tablet computers for three- to six year old children with drawing. [21] has been one of the earliest advocates for ICT for children from even the 1960's, indicated that computers open opportunities for new forms of learning that are far more consistent with the nature of young children than that of the majority of older people. This is because in his words, ICT tools are the technical tools that can help children tell and listen to stories, draw or create something, interact with other people etc. and that computers can offer for children's learning immediate positive reinforcement.

In countries such as the UK, early childhood education may actually be leading the way in developing best practice in the use of ICT to support positive learning experiences for children. The UK Foundation Stage (3 to 5 years) curriculum states that as part of their early childhood education, children should find out about and identify the uses of everyday technology, and that children should have opportunities to use ICT to support their learning [11]. Similarly, Scotland has developed ICT strategies for the early childhood education sector [12]. In 2005, the New Zealand Ministry of Education released a frame work to support the use of ICT in early childhood education.

A large portion of studies have highlighted the opportunities language use and social interaction that technology offers, along with increased motivation. For instance, [22] have illustrated many ways in which ICT can make rich contributions to children's literacy development, in the four interrelated areas of speaking, listening, reading, and writing. For instance they have discussed how "talking" word processors support young children's experimentation as they play with language. They highlight that these tools offer possibilities for children to compose and write without needing to have mastered the production of letters by hand. They also suggest using computers and printers to help children make signs, banners, and other props for pretend play, all of which will add interest and basic literacy skills to children's play and decisions, which will give children opportunities to use language.

Computers also make possible experiences and representations that cannot take place in the real world, providing new experiences and improved understanding. [23] explored how kindergarten and first grade students created and reflected upon digital photograph journals. [24] study focuses on the use of computers to enhance social, language, and cognitive skills. Clements (2002) in his study of the effects on mathematical thinking and problem-solving, mentions different studies showing that computer tasks can actually be more beneficial for pre-schoolers in counting, sorting and numeral recognition than those taught 
by a teacher. He also stresses that through computer tasks or properly chosen computer games young children can develop an increased ability to monitor their comprehension and problem-solving processes, make choices and decisions and improve their critical thinking skills. Some researchers like [25] also believe that children should be given opportunities to experience ICT as a tool with vast possibilities for communication and information retrieval/sharing. [26] observed that Children's early literacy and play experiences are shaped increasingly by electronic media, so in order to empower children and assist them in becoming competent and active participants in their environments, they must be given opportunities to develop "technological literacy", a new form of literacy, which is increasingly considered to represent an essential curriculum entitlement in any broad and balanced curriculum for the 21st century.

Children today live in a communication-rich environment. The models of communication they encounter in their everyday lives include a whole range of electronic and digital methods of communication [27]. Ghana is seen to be doing well in ICT, for instance, mobile penetration is about $106 \%$ with internet usage penetration increasing to $40.7 \%$ [28]. But how does this improvement reflect on education for it to be meaningful to the masses in Ghana? The ICT in Education Policy of Ghana requires the use of ICT for teaching and learning at all levels of the education system but silent on its use at the preschool and kindergarten level. Meanwhile the emphasis of the official curricula at the basic level of education is on the development of students' skills in operating ICTs but not necessarily using the technology as a means of learning subjects other than ICTs. The researcher's own checks and observation made over the years in some schools visited around the country do not show much integration of ICT is being done in the classrooms. There is also very little data on the availability of ICT tools and its usage in early childhood education in Ghana, this is because not many studies have been done in this area. For instance, background checks done at the Ministry of Education indicated that there is not much data on the use of ICT tools in the early year's classrooms.

The study therefore sought to explore the situation in Ghana's early years classrooms. It was to find out the type of ICT resources available in the various schools as well as to understand the current state of technology integration and to describe access, as to how the schools acquire their resources, whether they are available for children's use and to find out how well teachers are trained to integrate ICT in teaching.

\section{Methodology}

\subsection{Design/Sample}

The sequential exploratory design was used in order to gain insights into the availability and use of ICT tools in the early years in some Ghanaian schools as well as teachers' views on the integration of ICT in the early years. The design used both qualitative and quantitative methods in the data collection and analysis. This design was used in order to gain familiarity with the phenomenon of ICT in the early years in Ghana to inform further studies.

A cross section of early years teachers from two hundred and fifty (250) schools in three regions of Ghana were conveniently selected during supervision (teaching practice) period of the researcher's University for the study. The schools used represent both the Private and Government owned schools in Ghana. This is because the schools found all over the country are either Government (Public) owned or privately owned. Moreover public schools across the nation all follow the same curriculum and seem to have similar characteristics, for instance, teachers who teach them are trained from the Colleges of Education as well as the kind of textbooks and materials being used in lessons delivery.

The study employed the use of a Researcher made questionnaire which had closed and open ended questions as well as interview as the main instrument. The questionnaire sought to find out the type of technological resources available in the schools and whether they are available to the pupils, whether teachers are well trained to use and integrate ICT in their lessons. Fifty (50) out of the two hundred and fifty participants' were purposively selected and interviewed on the use and integration of ICT in early childhood education. The data collected were quantitatively and qualitatively analyzed.

\section{Results and Discussion}

The data collected were coded and keyed in SPSS and analyzed using simple percentages and frequencies for the quantitative data and the responses of the teachers' views on the use of ICT were analyzed qualitatively. It was noted that out of the 250 responses representing 250 schools, 145 (58\%) of them were public schools whilst 105 (42\%) were private. The results also showed that 155 representing (62\%) respondents are females with 95 (38\%) being males. The results of the responses were analyzed based on the research questions. It is worth noting that all the three regions used for the study were not equally represented since the number of schools identified 
in one region (urban) visited was more than in the other regions (rural).

\subsection{Kind of technological resources available in the school}

Here, list of ICT resources were identified for participants to tick those that were available in their schools. For the purpose of this research, the technological resources were grouped according to frequency of use as well as familiarity. It was recorded that a greater number of the schools did not have all the technological resources to help in the integration of ICT in teaching and learning as shown in Table 1. Forty four (44) participants representing (19\%) indicated they did not have any of the technological resources in their schools. It can be seen that the most common technological resources recorded (65) among all the schools is the computer (laptop or desktop) representing $28 \%$. And from the responses on the questionnaire, it was noted that both the private and public schools participants ticked the computer as the only resource found in their schools.

Table 1. Type of Technological resources found in the School

\begin{tabular}{|c|c|}
\hline Type of ICT resources & $\begin{array}{l}\text { Number } \\
\text { of } \\
\text { schools }\end{array}$ \\
\hline computer, tape recorder, radio & 17 \\
\hline $\begin{array}{l}\text { computer, digital camera, radio, } \\
\text { programmable toys. }\end{array}$ & 13 \\
\hline $\begin{array}{l}\text { computer, closed circuit-television set, } \\
\text { computer with internet, simulated } \\
\text { environments, electronic whiteboard, } \\
\text { interactive stories, computer games, } \\
\text { programmable toys, projectors, internet }\end{array}$ & 14 \\
\hline computer (desktop \& laptop) & 65 \\
\hline radio and tape recorder & 15 \\
\hline $\begin{array}{l}\text { computer, tape recorder, radio, closed- } \\
\text { circuit television, internet }\end{array}$ & 28 \\
\hline $\begin{array}{l}\text { computer, mobile phones, computer } \\
\text { with internet use, interactive stories }\end{array}$ & 19 \\
\hline $\begin{array}{l}\text { computer, closed - circuit television, } \\
\text { Projector }\end{array}$ & 22 \\
\hline $\begin{array}{l}\text { computer with internet access, } \\
\text { computer games, creativity and } \\
\text { communication software and tools, }\end{array}$ & 13 \\
\hline
\end{tabular}

\begin{tabular}{|l|l|}
\hline closed -circuit television & \\
\hline None & 44 \\
\hline Total & 250 \\
\hline
\end{tabular}

It was revealed that only fourteen (14) schools had all the technological resources, and these schools were all identified under private schools in the cities mostly in Greater Accra and Ashanti regions (Urban areas). Some Proprietors and teachers of such schools who were asked why the schools are having such resources, were of the view that they understand the need for children to be introduced to ICT because of its numerous advantages and for the fact that most of the children in their schools are coming from elite homes where they are already exposed to some of the resources like the computers, digital cameras as well as the internet. Among the 44 schools that indicated none resources, it was noted that more than half of the number were public schools. Some participants tried to assign reasons why their schools were not having the technological resources. Some indicated that they did not have classrooms, that is, a proper classroom where teaching and learning can comfortably take place. This is a situation the researcher observed to be true in a number of the schools visited, the Kindergarten and the lower classes were having their lessons under trees or dilapidated classrooms, and it is a common phenomena 'Schools under trees' in most of the remote areas and the outskirts of the various towns in Ghana which the Government is working hard to eliminate from the system. Understandably a school which is being held under tree cannot enjoy the use of any technological device. Others too commented that their communities were not hooked unto the national grid for electricity so they feel they are cut out from using some gadgets like the computer. Though these thoughts expressed by the teachers might be tangible, all boil down to the teachers' lack of knowledge in ICT as well as the technological resources that could be employed without the use of electricity and 'proper classroom'. For instance the lower grade of the tape recorder can use dry cells, the radio and the camera.

Even though the digital camera is less expensive and a powerful tool for children's learning not many schools and individual teachers have it, to enable teachers use it in supporting children's learning. It was gathered from some of the participants' responses that the computer was the only technological resource that can be used in enhancing children's learning. A number of the schools visited especially in the public schools had no idea of the listed technological resources made available in the questionnaire for them to tick as part of the tools used in enhancing children's 
learning. Meanwhile sight should not be lost on the fact that the term "ICT" encompasses much more than just computers. it includes computers, digital video cameras, creativity and communication tools; the internet, telephones, mobile telephones, programmable toys and 'control' technologies and closed circuit television; data projectors, electronic whiteboards and more [6].

\subsection{Acquisition of technological resources}

When asked how the schools are resourced with their technological tools, it was noted that all $42 \%$ who indicated their tools are school owned are all private schools. $31 \%$ of participants indicated that the Government resource them with the computers. This the Government does through its 'Better Ghana Agenda program.' 'The Better Ghana Agenda' is the current Government's policy of giving laptops to schools in Ghana to enhance the learning of ICT. This implies that all the public schools that identified themselves as having computers are all resourced by the Government. Nonetheless some teachers have seen the need for integration of ICT so they use their own personal resources in teaching. The pie chart in Figure 1 illustrates how the schools are resourced with technologies.

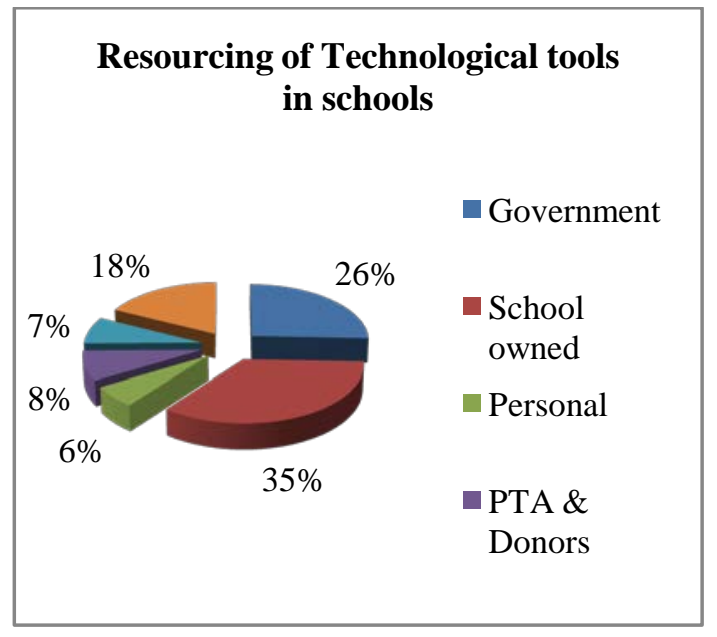

Figure 1. How the Schools are resourced with technological tools

In response to the question on whether the technologies are available to the children for learning, some participants responded they are available only when the lesson is on ICT, especially for the participants who indicated computers only. Others were quick to say that the computers are packed in the head teachers' office for safe keeping. For those have the closed circuit television, some mentioned that, they are not used by the children but rather the teachers use them for entertainment. Others were of the view that the only ICT tools (computers) available in their schools were not adequate to ensure adequate access by all the children.

On the issue of whether teachers are adequately trained to using ICT technologies (as shown in Figure 3) the mode on the responses, 'Not at all' was 98 (39\%). 53 (21\%) indicated they were not well trained, which implies $60 \%$ of the participants did not have knowledge in ICT. This findings corroborate with a similar study done in Kenya on ICT integration in Early Childhood Development teacher training Curriculum, which indicated that majority $(60.83 \%)$ of the teachers had no knowledge in ICT [29]. However the total number of 99 who indicated they are 'well', 'very well' and 'very well trained' is somehow assuring though not adequate. It was noted that the age range of most of the teachers teaching at the early years is between 41-50 and some of them find it difficult to learn how to use ICT tools in their teaching. Out of this 98 participants identified as not trained at all in the use of ICT technologies, 90 of them were found in the public schools. Some of them expressed the extent of their experience as not ever touching a mouse let alone type on the keyboard. Some of them indicated they have not had the opportunity of working on the computer and expressed the desire to learn to use it when given the opportunity. When asked about whether they would want to integrate ICT in their lessons, some of them commented; "how can I learn at this age to use ICT?”, “I was born before computers, so it will be difficult for me to use technologies”.

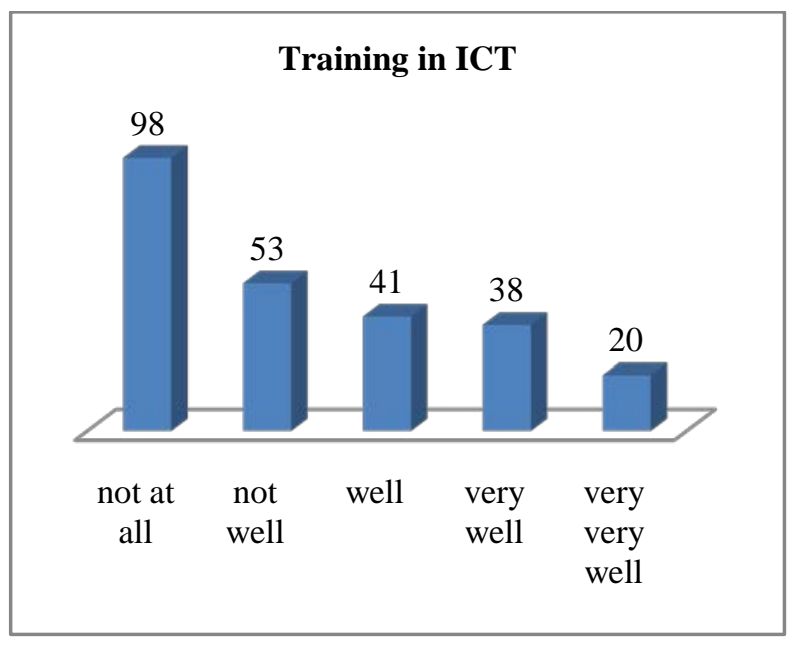

Figure 2. Responses on how trained teachers are in ICT

From these perspectives, it can be said that some of the teachers might not be ready to learn to use technology let alone integrate it in lessons. This could be seen from the data asking the teachers on how they integrate ICT. Out of the 250 responses a total of 123 representing (49\%) indicated they do 
not integrate ICT at all. This data is in line with the study done by [4] on the use of computers and internet as the supplementary source of educational material. Their study showed that less than $15 \%$ of teachers used the internet as an innovative way of improving teaching and learning. Here, only $7 \%$ fully integrated ICT. Figure 3 gives more highlight to the data. However, all the teachers were of the view that their teaching would be highly enhanced when they are able to integrate ICT in the teaching and learning process.

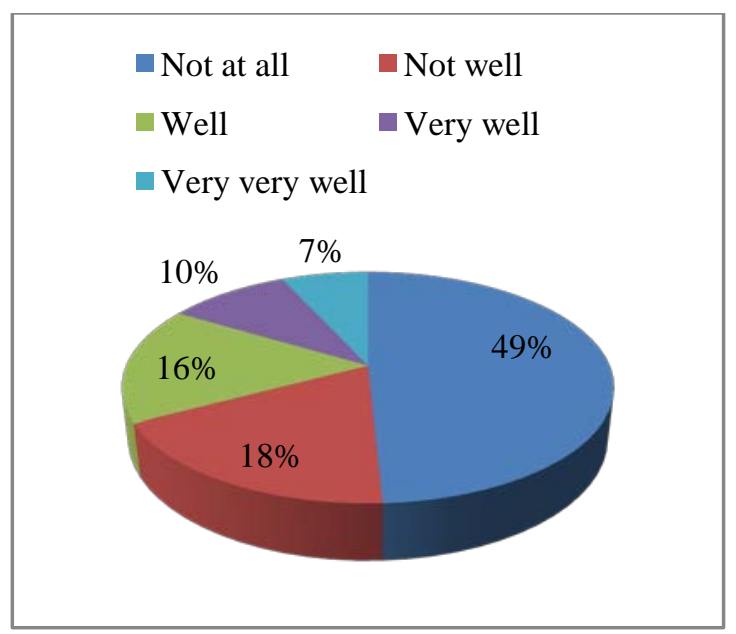

Figure 3. Integration of ICT in lessons

Teachers' views were sought on the use of ICT in the early years and $97 \%$ of them indicated that it is good children are introduced early since it might help them fit in the era of communication. It could be seen that the teachers in this study expressed an overall positive picture of the role ICT could play in ECE in spite of the controversy about the degree to which ICT is appropriate for young children to engage with. Some of the older women jokingly mentioned that it is good for the children to be exposed very early for them not to be like them. Some considered children are living in an increasingly technological world; it therefore becomes important that children are provided with meaningful experiences to explore technological resources to enable them to participate fully in the era of technology we find ourselves in. One teacher who indicated he integrates ICT was of the view that ICT stimulates the learning process when integrated. He believes this because it gives them the opportunity to communicate and share. This same view is reiterated by [25] who also believe that children should be given opportunities to experience ICT as a tool with vast possibilities for communication and information retrieval/sharing.

Here are some of the views as expressed by the some of teachers on the role of ICT in the early childhood teaching and learning environment;
Children need to know about the computer because that is the order of the day.

I believe integrating ICT in education stimulates the learning process.

I use it because pupils understand concepts best when they are given the right opportunity in understanding them better, which ICT tools offer. ICT provides a pathway to enhance and add value to children's learning.

The camera helps in making children see and understand concepts better since photos of concepts can be taken and made ideas clearer. ICT is the way we operate in the modern world-in so it is good children are let in.

ICT is proven tools to help pupils learn. The use of the tape recorder and computer for example help in reinforcing concepts taught, especially in language and literacy class.

However, the few participants (3\%) who felt it was not right for the children to be introduced to ICT early expressed concerns about risk, dangers and safety as expressed by some researchers [5], [13] that the children could be exposed to. They felt the early child might be exposed to inappropriate behaviors as exhibited in some programmes from the internet. They were worried that since children by nature are adventurous just showing them how to use the technological resources will enable them do it themselves with time. As a result when there is no or less supervision they could over use or use them wrongly to their disadvantage. One participant expressed the lack of confidence in teaching ICT and was afraid he might mislead the children so it was better the children are left till they get to the upper class.

\section{Conclusion}

The results of this study suggest that the integration of ICT in Ghana's early years' classrooms is not encouraging especially in the public schools. This is to say that ICT integration in the ECE in Ghana is limited. The technological resources needed to help the integration are not available and the most common resource available in the schools is the Computer which is even not adequate. It came to light that most of the teachers are not trained or have no or little knowledge in the use of ICT to enable them integrate it in their lessons. It appeared that the lack of prior experience indicated by some teachers might not be a major inhibitor to their learning to use and integrate ICT when given the opportunity. It is assuring though to learn that some schools have acknowledged the need to integrate ICT in education, much is needed to be done. From the literature, it has been established that Children's early literacy and play experiences are shaped 
increasingly by electronic media [26], it is therefore important that our children are empowered and given opportunities to develop "technological literacy”, which will make them competent and active participants in their environments.

\section{Recommendations}

Though ICT forms part of the subjects found in the Ghanaian basic school curriculum there is no policy binding schools to use and integrate its teaching at the preschool and the kindergarten level. Even at the basic level which has ICT as part of their curriculum, for that matter ICT syllabus, is only taught largely as a subject with children being exposed to the basic knowledge of the parts of the computer other than being integrated into the children's learning process. It is therefore recommended that a curriculum policy be put in place to bind the use of technological tools in the teaching and learning process in their classrooms as done in other countries like New Zealand, Emphasis therefore should be on the training of teachers in ICT because they are the central forces for which the integration of ICT in children's learning will be made possible. In addition it is recommended that pre service teachers and teachers be trained purposely on how to integrate ICT. This is because some of the teachers have the basic knowledge of ICT but do not know how to integrate it in their lessons. Also the Government should increase the number of computers being given to the various schools to reach all the schools as well as providing to the schools other technological resources like the cameras, closed circuit television sets, projectors and tape recorders, just to mention a few. Teachers in Early Years are to be educated on other technologies available for teaching children other than the micro computers.

\section{Acknowledgements}

I am grateful to all participants and schools used for this study. I appreciate the efforts of my friend Mrs Ruby Hanson for her encouragement and support. I express my warm thanks to my Faculty board and my Vice Chancellor for their inputs. My final appreciation goes to the Steering Committee CICE-2014 for giving me this opportunity.

\section{References}

[1] Essuman, S. O. \& Appiah- Boateng, P. (2013). Faculty and Students Collaboration in an online courseware development: Lessons and challenges. Conference Paper presented at the e-Learning Innovations Conference \& Expo, Nairobi, Kenya. $25^{\text {th }}$ $30^{\text {th }}$ July, 2013.
[2] Hanson, R., \& Nsiah Asante, J. (2013). An exploration of experiences in using the hybrid Moodle approach in the delivery and learning situations at the University of Education, Winneba, Ghana. Computational and Mathematical Methods in Science and Engineering. Vanderbijlpark, Gauteng: Vaal University of Technology.

[3] Kasule M. Y. (2013). Increase of Internet usage in Ghana and Its Implications retrieved 28/1/14 from http://www.ghanaweb.com/GhanaHomePage/features/art ikel.php?ID=286132

[4] Amenyedzi, F. W. K., Lartey, M. N. \& Dzomeku, M. B. (2011). The Use of Computers and Internet as supplementary source of Educational material: A case study of the Senior High Schools in the Tema Metropolis in Ghana. Contemporary Educational Technology, 2(2), 151-162.

[5] New Zealand Council for Educational Research (2004). The Role and Potential of ICT in Early Childhood Education. A Review of New Zealand and International Literature. Wellington.

[6] Siraj-Blatchford, I., Siraj-Blatchford, J. (2006). A Guide to Developing the ICT Curriculum for EarlyChildhood Education. Trebtham Books, UK.

[7] Bolstad R. (2004) The Role and Potential of ICT in Early Childhood Education: A Review of New Zealand and International Literature. New Zealand Council For Educational Research, Wellington.

[8] Siraj-Blatchford, J., Whitebread, D. (2003). Supporting Information and Communication Technology in the Early Years. Supporting Early Learning. Open University Press, UK.

[9] Hayes, M., Whitebread, D. (eds.) (2006). ICT in the Early Years. Open University Press, England. ICT in Pre-School: A ‘Benign Addition'? (2002) A review of the literature on ICT in pre-school settings. Learning and Teaching Scotland, Early Education Support.

[10] Ministry of Education (2009). Information and Communication Technology (ICT). Book 20. Available www.educate.ece.govt.nz/ /media/Educate/Files/Referen ce\%20Downloads/ex/ECEBk20/ECEBk20Full.pdf (accessed 10 January 2014).

[11] Becta (2004). Video conferencing in the curriculum. Case study 2: Chalvey Early Years Centre, Slough. Estorytelling. British Educational Communications and Technology Agency. Retrieved 30 June 2013, from http://www.ltscotland.org.uk/earlyyears/casestudies.asp

[12] Learning and Teaching Scotland. (2003b). Early learning, forward thinking: the policy framework for ICT in early years. Scotland. Retrieved 25 March 2013, from http://www.ltscotland.org.uk/earlyyears/files/ict_framework. pdf

[13] Byron, T. (2008). Safer Children in a Digital World. The Report of the Byron Review. Department for Children, Schools and Families Publications, Sherwood Park, UK. 
[14] Cordes, C., \& Miller, E. (Eds.). (2000). Fool's gold: A critical look at computers in childhood. College Park, Maryland: Alliance for Childhood.

[15] Healy, J.M. (1998, May) Understanding TV's effect on the developing brain. AAP News: The Official News Magazine of the American Academy of Pediatrics. Retrieved November 15, 2000, from the World Wide Web: www.aap.org/advocacy/chm98nws.htm

[16] Haugland, S. (2000) Early childhood classrooms in the 21st century: using computers to maximise learning. Young Children 55, 1, 12-18.

[17] Yelland, N. J. (1999). Technology as Play, Early Childhood Education Journal, 26 (4): 217-25.

[18] McRae, D. (2001). What to make, and why; Principles for the design and development of online curriculum content. Curriculum Corporation.

[19] Wang, C. \& Hoot, J. (2006). Information and communication technology in early childhood education. Early Education and Development, 17(3), 317-322.

[20] Chen, D. \& Couse, L. (2009). Exploring the viability of tablet computers in early education: Considering the principles of Developmentally Appropriate Practice. In I. Gibson et al. (Eds.), Proceedings of Society for Information Technology \& Teacher Education International Conference 2009 (pp. 3251-3254). Chesapeake, VA: AACE. Retrieved May 8, 2014 from http://www.editlib.org/p/31147.

[21] Papert, S. (1996). The Connected Family: Bridging the digital generation gap. Atlanta, Georgia. Longstreet Press.

[22]Van Scoter, J., \& Boss, S. (2002). Learners, language, and technology: Making connections that support literacy:
Northwest Regional Educational Laboratory. Retrieved 24 June, 2013, from

http://www.netc.org/earlyconnections/pub/index.html

[23] Ching, C. C., Wang, X. C., Shih, M., \& Kedem, Y. (2006). Digital photography and journals in a kindergarten - first-grade classroom: Toward meaningful technology integration in early childhood education. Early Education and Development, 17(3), 347-371.

[24] Seng, S. (1998, November). Enhanced learning: Computers and early childhood education. Paper presented at the Educational Research Association Conference, Singapore. (ERIC Document Reproduction Service No. ED 431 524)

[25] Haugland, S. W. (1999). What role should technology play in young children's learning? Part 1. Young Children 54(6):26-31.

[26] Luke, C. (1999) What next? Toddler netizens, playstation thumb, techno-literacies. Contemporary Issues in Early Childhood 1,1, 95-100. Retrieved 5 February 2013, from http://www.triangle.co.uk/ciec/

[27] Siraj-Blatchford, I., Siraj-Blatchford, J. (2003). More than Computers: Information and Communication Technology in the Early years. The British Association for Early Childhood Education, London.

[28] National Communications Authority (NCA). Retrieved March, 2013 from http://www.nca.org.gh/73/34/News.html

[29] Ndiritu AW, Mburu D, Kimani G. "ICT integration in Early Childhood Development teacher training Curriculum: Need to start from the beginning.” In: $3^{\text {rd }}$ KIE Education symposium. KENYA INSTITUTE OF EDUCATION; 2013 